\title{
A survey of volunteer reconstructive surgery performed outside of Canada by Canadian plastic surgeons
}

\author{
Colleen M Fitzcharles-Bowe MD ${ }^{1}$, Donald H Lalonde MD MSc FRCSC ${ }^{2}$
}

\begin{abstract}
CM Fitzcharles-Bowe, DH Lalonde. A survey of volunteer reconstructive surgery performed outside of Canada by Canadian plastic surgeons. Can J Plast Surg 2005;13(1):53-56.
\end{abstract}

BACKGROUND: Members of the Canadian Society of Plastic Surgeons have been offering humanitarian services to countries outside of Canada since the 1960s.

OBJECTIVE: To document the extent of voluntary reconstructive services performed by members of the Canadian Society of Plastic Surgeons.

METHOD: A survey was sent to all members of the Canadian Society of Plastic Surgeons asking them to list the extent of their voluntary services.

RESULTS: Over 80 Canadian Society of Plastic Surgeons members have performed voluntary reconstructive services with more than 40 organizations in over 60 countries.

CONCLUSION: These voluntary services provide a significant benefit to patients around the world and are rewarding for the surgeons who perform them.

Key Words: Canadian Society of Plastic Surgeons; Volunteer reconstructive services
Enquête sur des interventions de reconstruction pratiquées bénévolement à l'extérieur du pays par des plasticiens canadiens

CONTEXTE : Des membres de la Société canadienne des chirurgiens plasticiens offrent leurs services à l'étranger, à titre humanitaire, depuis les années 60

OBJECTIF : Documenter l'étendue des services de reconstruction, offerts bénévolement par les membres de la Société.

MÉTHODE : Un questionnaire a été envoyé à tous les membres de la Société leur demandant d'indiquer l'étendue de leurs services bénévoles. RÉSULTATS : Plus de 80 membres de la Société ont pratiqué bénévolement des interventions de reconstruction, et ce, auprès de plus de 40 organisations, dans plus de 60 pays.

CONCLUSION : Les services ainsi offerts procurent des bienfaits considérables à des patients partout dans le monde et sont source de gratification pour les chirurgiens eux-mêmes.
For over four decades, members of the Canadian Society of Plastic Surgeons have been offering volunteer reconstructive services to countries outside of Canada. Because of these efforts, children and, occasionally, adults who were ostracized in their countries based on their appearances have been given a new image. They have been given a second chance to re-enter society as complete persons. In the fall of 2003, we decided to survey the Canadian Society of Plastic Surgeons to document the extent of its volunteer reconstructive services performed outside of Canada.

\section{METHODS}

A '3rd World Surgery' survey sheet was sent to all members of the Canadian Society of Plastic Surgeons, asking them to list the countries in which they performed volunteer services. They were also asked to list the years that they served, the types of operations they performed and the organizations with which they were affiliated. There was also a section left open for comments about the experiences. These data were then calculated and placed into tables.

\section{RESULTS}

Canadian plastic surgeons who have volunteered in countries other than Canada are listed in Table 1. Types of services provided are listed in Table 2 and countries in which Canadian plastic surgeons have volunteered are listed in Table 3. Organizations with which Canadian plastic surgeons have served are listed in Table 4.

\section{DISCUSSION}

In this survey, we found that 85 members of the Canadian Society of Plastic Surgeons had volunteered their services to countries outside of Canada. These services were mostly in the form of surgical procedures; however, teaching, lectures and general medical assistance were also given. Although cleft lip and palate reconstruction was the most common procedure performed, surgery ranged from general plastic surgery to highly skilled war reconstruction and microsurgery. Surgery was maily focused on children, but some adults were also operated on.

\footnotetext{
${ }^{1}$ Division of Plastic Surgery, Dalhousie University, Halifax, Nova Scotia; ${ }^{2}$ St John Regional Hospital, Saint John, New Brunswick

Correspondence: Dr Donald H Lalonde, St John Regional Hospital, PO Box 2100, Saint John, New Brunswick E2L 4L2.

Telephone 506-648-7950, fax 506-652-8042, e-mail drdonlalonde@nb.aibn.com
} 
TABLE 1

Plastic surgeons who have served in countries outside of Canada (85 total)

\begin{tabular}{|c|c|c|}
\hline Aliyah, Abdulrazzak & Jewer, David & Oxley, Paul \\
\hline Bederman, Michael & Kay, Peter & Paletz, Justin \\
\hline Bell, Michael & Kemsley, Graham & Panthaki, Zurin \\
\hline Bendago, Mansour & Kesarwani, Atul & Parkhill, Winston \\
\hline Binhammer, Paul & Knight, Charles R & Peters, Walter \\
\hline Bite, Uldis & Korentager, Richard & Rai, Kimit \\
\hline Born, Gunter & Laberge, Louise & Schwarz, Gaston \\
\hline Brown, W Lorne & Lacey, Martin & Schultz, Richard \\
\hline Burget, Gary C & Lalonde, Don & Scilley, Chris \\
\hline Carlsen, Lloyd & La Scala, Giorgio & Scoracki, Roman J \\
\hline Carr, Nicholas & Levine, Ronald & Sigurdson, Leif \\
\hline Chasmar, Leslie & Lessard, Lucy & Skanes, Susan \\
\hline Clarke, Howard & Levis, Carolyn & Son-Hing, Q \\
\hline Cluett, M Joy & Lindsay, Robert & Stephenson, DG \\
\hline Cook, William A & Lindsay, WK & Stuart, William A \\
\hline Dado, Diane & Lindsay, WRN & Tate, Laura \\
\hline Davidson, John & Lobay, Gary & Taylor, John R \\
\hline Drever, Michael & Manktelow, Ralph & Thompson, Grant \\
\hline Duncan, Mary Jean & McPhalen, D & Tweed, Anne \\
\hline Faibisoff, Burt & Miles, Duncan & Voice, Sandra \\
\hline Fisher, David M & Morris, Steve & Voloshin, P \\
\hline Freiberg, Arnis & Murray, Ken A & Ward, David K \\
\hline French, Rod & Naysmith, David & Waters, Linda \\
\hline Gareau, Paul & Neligan, Peter & Wells, Neil \\
\hline Ginttre, Martin J & Nickerson, Duncan & Wilkes, Gordon \\
\hline Gutek, Phillip & Nootems, Jean B & Williams, Bruce \\
\hline Hong, Colin & O'Hare, Terrance & Wilson, Ken \\
\hline \multirow[t]{2}{*}{ Hurst, Larry } & Olesen, $\mathrm{P}$ & Windle, Brian \\
\hline & & Zuker, Ron \\
\hline
\end{tabular}

This list includes only those surgeons who responded to the survey

TABLE 2

Types of services rendered (16 total)

\begin{tabular}{ll}
\hline Burns reconstruction & Gynecology \\
Cleft lips/palates & Hand surgery \\
Congenital anomalies correction & Malaria care \\
Craniofacial surgery & Microsurgery \\
Facial surgery & Pediatric plastic surgery \\
Free tissue transfer & Teachings/lectures \\
General medicine & Trauma reconstruction \\
General plastic surgery & War reconstruction \\
\hline
\end{tabular}

Canadian plastic surgeons served in 64 different countries. Ecuador, China, Kenya and Vietnam were the countries most frequently visited. Among the least frequently visited countries were Albania, Tibet, Yap and Zimbabwe.

A total of 44 organizations were involved in organizing the volunteer services. Operation Smile was affiliated with most of
TABLE 3

Countries in which Canadian plastic surgeons have served (62 total)

\begin{tabular}{|c|c|c|c|}
\hline Country & $\mathbf{n}$ & Country & $\mathbf{n}$ \\
\hline Afghanistan & 1 & Malawi & 2 \\
\hline Albania & 1 & Malaysia & 2 \\
\hline Armenia & 2 & Mexico & 9 \\
\hline Bangladesh & 2 & Morocco & 1 \\
\hline Bolivia & 6 & Nepal & 4 \\
\hline Bosnia & 2 & Nicaragua & 1 \\
\hline Brazil & 3 & Nigeria & 3 \\
\hline Britain & 1 & Palau & 1 \\
\hline Burma & 2 & Panama & 1 \\
\hline Cambodia & 3 & Paraguay & 1 \\
\hline China & 14 & Peru & 9 \\
\hline Colombia & 3 & Philippines & 7 \\
\hline Ecuador & 18 & Phungpi & 1 \\
\hline Egypt & 1 & Republic of the & 1 \\
\hline El Salvador & 1 & Congo & \\
\hline Estonia & 1 & Romania & 1 \\
\hline Grand Cayman & 1 & Russia & 1 \\
\hline Guatemala & 7 & Saipan & 1 \\
\hline Guyana & 3 & Saint Lucia & 1 \\
\hline Haiti & 1 & Santo Domingo & 1 \\
\hline Honduras & 9 & South Africa & 2 \\
\hline India & 5 & Tanzania & 2 \\
\hline Indonesia & 3 & Thailand & 1 \\
\hline Israel & 1 & Tibet & 1 \\
\hline Jamaica & 3 & Tunisia & 1 \\
\hline Jordan & 1 & Turkey & 1 \\
\hline Kenya & 11 & Uruguay & 1 \\
\hline Laos & 1 & Venezuela & 1 \\
\hline Latvia & 2 & Vietnam & 11 \\
\hline Libya & 1 & West Bank & 1 \\
\hline \multirow[t]{2}{*}{ Lithuania } & 1 & Yap & 1 \\
\hline & & Zimbabwe & 1 \\
\hline
\end{tabular}

these trips; however, a number of plastic surgeons organized self-sponsored trips. Most of our plastic surgeons found the experience very rewarding and had plans for future trips.

\section{SAMPLE CASE PRESENTATIONS}

Case 1: Kunming, China

A 10-year-old boy arrived by himself at the hospital on the last day of surgery. The door had not only been closed to any new patients arriving, but many more had been turned away because we were past our limit of the number of patients we could operate on. He had a note from his father which was translated to us: "Please operate on my son's lip. I can't come with him because of my responsibilities on the farm". We learned that the boy had managed to find us after three days and $125 \mathrm{~km}$ of bicycle travel! He slept by the roadside at night. We squeezed him into those last few hours of surgery that day (Figure 1), and a few team members pitched in to buy bus fare for him and his bicycle to return to his home the next day. 
TABLE 4

Organizations with which Canadian plastic surgeons have served (44 total)

\begin{tabular}{|c|c|}
\hline Aloha Medical Mission & Latvia Association of Plastic \\
\hline AMREF & Surgeons \\
\hline American Society of Hand Surgeons & Lister Hand Fellowship \\
\hline American Society of Plastic Surgeons & Loyola \\
\hline AUCC & Medecines sans frontiere \\
\hline British Plastic Surgery Society & Medical Missions Foundation \\
\hline Canadian- China Child Health Foundation & Medishare \\
\hline Care- Medico & Operation Common Hope \\
\hline Children Action Foundation & Operation Good Samaritan \\
\hline Christian Medical \& Dental Society & Operation Rainbow Canada \\
\hline CIDA & Operation Smile \\
\hline CITA & Peruvian- American Medical \\
\hline Citizen Ambassador & Association \\
\hline CUSO & Physicians of World Peace \\
\hline El Cielo Para Los Ninos & Plasticos \\
\hline del Ecuador & Poco a Poco \\
\hline EMAS & Private donations \\
\hline Healing The Children NE & Pro Cristo \\
\hline Health for Humanity & Project outreach \\
\hline Hope People to People & Queen's Medical Outreach \\
\hline International Relief Teams & Reconstructive Surgery \\
\hline Interplast & Foundation \\
\hline \multirow[t]{3}{*}{ Kindness Action Surgery } & Self Organized \\
\hline & SMART \\
\hline & Support Fund Belgium \\
\hline
\end{tabular}

AMREF African Medical and Research Foundation; AUCC Association of Universities and Colleges of Canada; CIDA Canadian International Development Agency; CITA Christians in Theatre and Arts; CUSO Canadian University Services Overseas; EMAS Evangelical Medical Aid Society; SMART Surgical and Medical Action Relief Teams

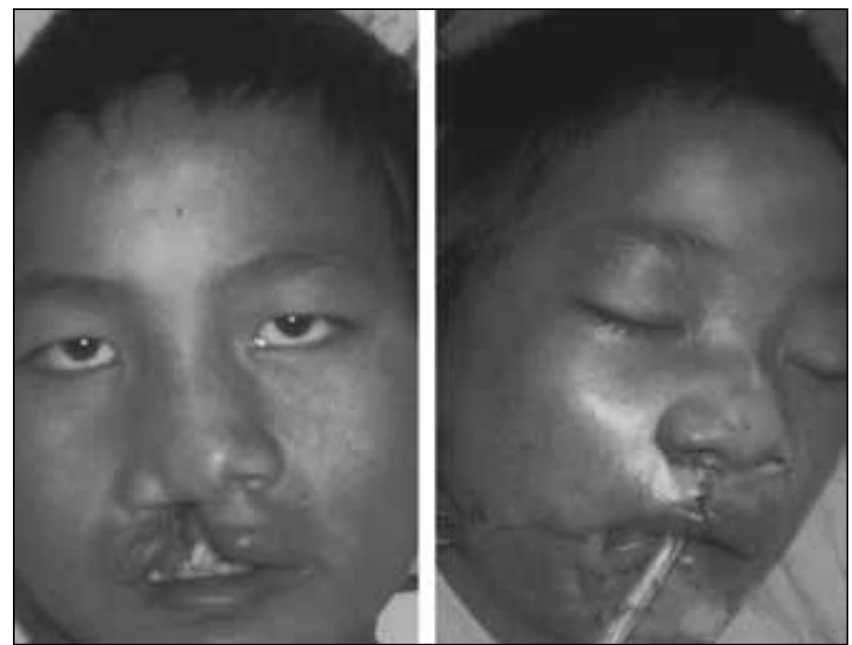

Figure 1) Before and after cleft lip repair in China

\section{Case 2: Nakhon Si Thammarat, Thailand}

An eight-year-old boy lost all of the function of his eight fingers and two thumbs due to severe burns. Because no plastic surgery was available, they became stuck into his palms with the healing process (Figure 2). We were able to release his dominant thumb from the palm of his hand with a $3 \mathrm{~h}$ operation that
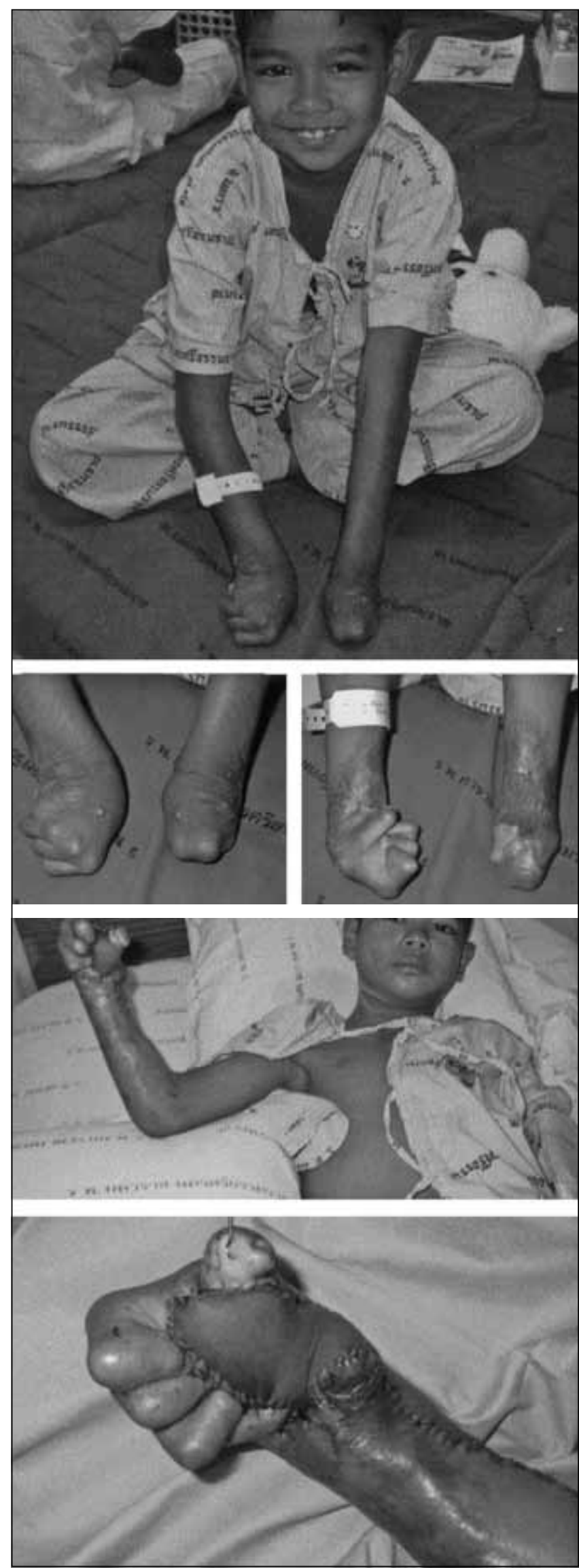

Figure 2) Hand burns before surgery (upper three photos) and after thumb release (lower two photos) 


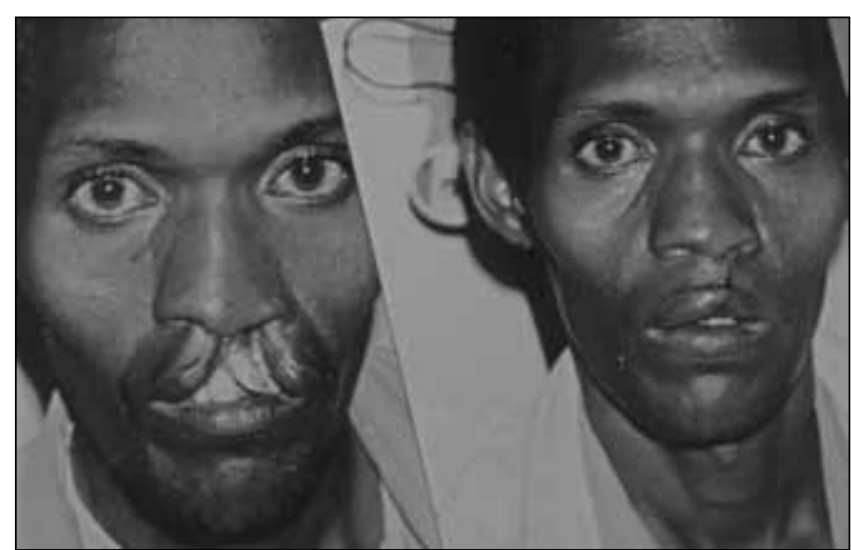

Figure 3) Before and after cleft lip repair in Kenya

transferred skin from the forearm to free up the thumb. He did not cry with the painful dressing removal the day after surgery. Tears of joy came to his eyes as he moved his thumb for the first time in four years. He would now have some independence to feed himself and use the washroom by himself.

\section{Case 3: Mombasa, Kenya}

This handsome, 37-year-old man came from a village where surviving with his deformity was more difficult than in other places because of local superstition. He remained hidden during most of the daytime hours and only appeared in public with a shawl covering his face. Imagine being his age and never having had the experience of sharing a gentle kiss. As he was older than most of the children who get priority, he risked not being able to get an operation. Rather than let this happen, we performed his surgery as 'one last extra' at the end of the day, under local anesthesia. He is seen in Figure 3 just five days after surgery in our follow-up clinic, with a chance to lead a normal life.

\section{CONCLUSIONS}

The members of the Canadian Society of Plastic Surgeons continue to offer excellent humanitarian services to countries outside of Canada. These services not only make an impact on the patients and countries that benefit from them but are also very rewarding and satisfying to the surgeons who perform them.

ACKNOWLEDGEMENTS: The Division of Plastic Surgery, Dalhousie University, Halifax, Nova Scotia; the Division of Plastic Surgery, Saint John, New Brunswick; and the members of the Canadian Society of Plastic Surgeons. 